The University of San Francisco

USF Scholarship: a digital repository @ Gleeson Library | Geschke Center

Media Studies

College of Arts and Sciences

$5-2019$

Extra-Activism: Counter-Mapping and Data Justice

Dorothy Kidd

Follow this and additional works at: https://repository.usfca.edu/ms

Part of the Gender, Race, Sexuality, and Ethnicity in Communication Commons, and the Indigenous Studies Commons 


\title{
Extra-activism: counter-mapping and data justice
}

\author{
Dorothy Kidd, \\ University of San Francisco \\ kiddd@usfca.edu
}

\section{$\underline{\text { Pre-publication version }}$}

To cite this article: Dorothy Kidd (2019) Extra-activism: counter-mapping and data justice, Information, Communication \& Society, 22:7, 954-970, DOI:

10.1080/1369118X.2019.1581243

To link to this article: https://doi.org/10.1080/1369118X.2019.1581243

Published online: 13 May 2019. 


\begin{abstract}
Neither big data, nor data justice are particularly new. Data collection, in the form of land surveys and mapping, was key to successive projects of European imperialist and then capitalist extraction of natural resources. Geo-spatial instruments have been used since the fifteenth century to highlight potential sites of mineral, oil, and gas extraction, and inscribe European economic, cultural and political control across indigenous territories. Although indigenous groups consistently challenged maintained their territorial sovereignty, and resisted corporate and state surveillance practices, they were largely unable to withstand the combined onslaught of surveyors, armed personnel, missionaries and government bureaucrats.
\end{abstract}

This article examines the use of counter-mapping by indigenous nations in Canada, one of the globe's hubs of extractivism, as part of the exercise of indigenous territorial sovereignty. After a brief review of the colonial period, I then compare the use of counter-mapping during two cycles of indigenous mobilization. During the 1970s, counter-mapping projects were part of a larger repertoire of negotiations with the state over land claims, and served to re-inscribe first nation's long-standing history of economic, social and cultural relations in their territories, and contribute to new collective imaginaries and identities. In the current cycle of contests over extractivism and indigenous sovereignty, the use, scope and geographic scale of counter-mapping has shifted; maps are used as part of larger trans-media campaigns of Indigenous sovereignty. During both cycles, counter-mapping as data justice required fusion within larger projects of redistributive, transformative and restorative justice. KEYWORDS: counter-mapping, extractivism, Indigenous sovereignty, data activism, data justice, compositional enquiry. 


\section{Introduction}

The map in the stairwell of the house in the Arctic town of Spence Bay literally turned the world upside down. Rather than their usual representation as feature-less blank white spaces on the upper margins, the Inuit territories were in the center, and their communities, waterways and important sites were named in Inuktitut. At that time in 1989, the Inuit were negotiating with the Canadian government to establish their own self-governed territory of Nunavut. "The power of data, including maps, graphs and visualizations," as Renzi and Langlois remind us, "not only resides in its capacity to produce knowledge, but also in its ability to shape perceived realities." "Whoever owns, controls and has the right to access and analyse data" holds tremendous political and ideological power. "Data has transformative and affective potential" and "activists are drawing on data as a way to provide means for social transformation" $(2015,202)$.

This article discusses the contest over maps, and other cartographic visualizations, as one of the longest-running examples of data activism. Data collection, in the form of land surveys and mapping, has been practiced on a global scale since at least the fifteenth century, as the "landscapes of the world became geographic objects of European power" (Sluyter, 2001). Cartographers acted for the imperial powers and their corporate backers to survey and stake claims for gold, silver, oil and other extractable resources, assemble data about the Indigenous populations they were displacing (Chapin, Lamb \& Threlkeld, 2005), and "reinforce their worldviews and status" (Willow, 2013, p. 872). Although surveyors and cartographers depended on the support of Indigenous people, their generosity was mostly repudiated; once their knowledge was extracted, they were largely unable to withstand the combined onslaught of surveyors, armed groups, missionaries, miners and government bureaucrats, and were violently displaced from their territories. 
These conflicts over territorial sovereignty and its representation, and the associated values, systems of knowledge and of law, are nowhere more intense than in Canada, a settler colonial state founded on extractivist economies, and the parallel dispossession of Indigenous peoples and un-making of their societies. During the nineteenth century, maps were one of the key disciplinary technologies in the management of dispossession in Canada, essential to organizing colonial space (Harris, 2004). Once minerals, oil and natural gas were found, the colonial government quickly intervened on behalf of the extractive industries to negotiate treaties, land claims and other contracts with Indigenous groups.

This process continues to this day, as Canada continues to be one of the global hubs of the mining, oil and natural gas industries, employing sophisticated cartographic practices in extensive domestic and international operations. The Canadian state continues to support the extractive industries with ever more corporate friendly laws, taxation policies, and permissive conditions, a key stratagem of neoliberal capitalism (Kidd, 2015). However, this expansion of non-renewable resources, and especially their pipelines, is encountering fierce opposition from Indigenous, environmental and other movements, and municipal councils across the country, which are acting in protection of the environment, and in support of Indigenous sovereignty.

\section{Counter-mapping, Indigenous resurgence and data justice}

Nancy Peluso first introduced the concept of counter-mapping to describe projects of Indigenous peoples in Kalimantan, Indonesia who were contesting state land-use plans (1995). Harris and Hazen define counter-mapping as "any effort that fundamentally questions the assumptions or biases of cartographic conventions, that challenges predominant power effects of mapping, or that engages in mapping in ways that upset power relations" (115). ${ }^{1}$ Counter-mapping is similar to other forms of data activism, in which data 
is used as a techne to create knowledge about the world, denounce dominant representations, shed light on discrimination and injustice, and establish alternative and social categories (Bruno, Didier \& Vitale, 2014, Milan \& van der Velden, 2016). In Canada, Indigenous first nations have employed counter-mapping as part of a complex repertoire of resistance to extractivist projects, and in political negotiations with the Canadian state. Sometimes, as Michi Saagiig Nishnaabeg member and professor Leanne Betasamosake Simpson describes, they have also used the process as mark their dispossession and as a "tool to generate cohesion, pride and rebuilding” within their communities $(2017,12)$.

This article links contests over mapping and cartographic practices between two types of capitalist accumulation ---the so-called "new oil" of digital data extraction and the much older material extraction of oil, minerals, and other non-renewable resources. It is a project with biographical, political and intellectual reasons. In the 1980s, I worked for Indigenous broadcasting groups in northern Canada, and became aware of just how imbricated the Canadian state and my own subjectivity and status as a white settler is in capitalist practices of extraction. In 1984, working for OKâlaKatiget Communications, I met some of the participants in Our Footprints are Everywhere: Inuit Land Use and Occupancy in Labrador, a mapping project that was instrumental in the Labrador Inuit Land Claims Agreement.

Then in 2011, I listened in Vancouver as Indigenous scholars Audra Simpson, Glenn Coulthard and Alfred Taiaiake lectured on 'Indigenous resurgence' projects of art, scholarship and land-based practices for self-determination. Taiaiake drew a direct line between the Canadian Government's renewed commitment to extractivism and the continuing dispossession of Indigenous peoples. More recently, in 2015, Coulthard said that "indigenous land-based direct action is positioned in a very crucial and important place for radical social change," especially “in settler-colonial political economies like Canada, which 
is still very much based on the extraction and exploitation of natural resources" (Epstein, 2015).

Inspired by their call, this article is part of a larger study of the use of contentious communications practices in the contest between capitalist extractivism and its contentious counterpart, extra-activism; ${ }^{2}$ in which I utilize the autonomist Marxist composition methodology elaborated by Nick Dyer-Witheford to query the forms of counter-power possible in a highly globalized capitalism (2008). ${ }^{3}$ I examine the communicative goals, vision, form, content, direction and circulation of specific struggles, situated within the larger cartography and changing composition of contentious subjects, technologies and media practices. ${ }^{4}$

In this article, I first review the colonial legacy of mapping and then compare the use of counter-mapping in two cycles of Indigenous resistance to oil pipelines - the precedentsetting use of counter-mapping by the Dene and Inuit during the 1970s (Eades, 2015, Bryan \& Wood, 2015, Dalton \& Stalman, 2018); and the current use of counter- mapping within the Unist'ot'en and Secwepemc anti-pipeline campaigns. I conclude that these cases of Indigenous counter-mapping provide some important lessons for a more comprehensive understanding of data justice. Echoing what MIT professor and data activist Sasha CostanzaChock said at the Data Justice conference, they provide examples of data activism fused within larger projects of redistributive, transformative and restorative justice, which optimize their liberation and not the capitalist market (2018).

\section{Extra-activism}

In her book As We Have Always Done, Leanne Betasamosake Simpson elaborates on the close link between extractivism and capitalism, and how a radical Indigenous resistance is key to challenging both (2017, p. 76). In an interview with Naomi Klein, she said: 
Extraction and assimilation go together. Colonialism and capitalism are based on extracting and assimilating. The act of extraction removes all of the relationships that give whatever is being extracted meaning. Extracting is taking. Actually, extracting is stealing - it is taking without consent, without thought, care or even knowledge of the impacts that extraction has on the other living things in that environment. That's always been a part of colonialism and conquest. Colonialism has always extracted the indigenous - extraction of indigenous knowledge, indigenous women, indigenous peoples (2013).

Argentinian Maristela Svampa calls the extractivist way of thinking the "eldoradista" vision $(2015$, p. 49). This idea of easily obtainable treasure continues to capture the imaginations of many, reinforcing Margaret Thatcher's slogan that there is no alternative to the system of global capitalism, and the continuing exploitation of non- renewable natural resources. Nevertheless, as notable extra-activist campaigns in Standing Rock, U.S.A, and other world centers have made more visible, many Indigenous nations never ceded their very different worldviews, ways of knowing, and ethics of collective responsibility for all the life forms within the territories they held in common. In Canada, many first nations never ceded collective title to the land they held pre-contact, nor their sovereign rights to live, productively utilize and govern their territories.

\section{Colonial mapping: making terra nullius}

Coulthard and others have documented the complex system of reciprocity and obligations practiced by many Indigenous communities in their relations between humans and other beings, and rocks, trees, lakes and rivers, in order to ensure their survival and wellbeing over all time (2014). Rather than individual plots of property to be exploited, territory was understood as a collective ecology held in common by an ethical framework that he calls "grounded normativity." As part of their customary systems of collective tenure, Indigenous communities had sophisticated mapping practices. They developed intimate knowledge of the people, fish, land and sea animals, ice, waterways, plains and forests as they traversed, canoed and kayaked long distances before transport was mechanized. They employed 
landmarks, named significant places, and created narratives about the different sites, sources of food, survival techniques, social gatherings and collective histories as ways to remember, archive, school the young, and gift to friends and family. For example, the inuksuk, now widely marketed as a Canada-branded tourist trinket, was part of the Inuit system of landmarks for travel routes, fishing and hunting spots, spiritual sites, camps, and memorials. Maps provided one of the primary means of communication between the colonizers and the Indigenous peoples (Eades, 2015). European cartographers were usually dependent on Indigenous peoples' knowledge, if seldom acknowledged (Willow, 2013). The early European maps were often little more than outlines of the elements needed to locate prospective resource developments; they erased much of the life of the people and the rich animate and inanimate forms of the environment they depicted (Harris, 2004). These maps became key to European control, and what James Scott calls the "legibility" over local peoples, territories, and resources, "reach[ing] across vast distances, flattening space, compartmentalizing it, renaming it, and assimilating these representations in the geometry of the Cartesian grid" (Harris, 2004, p. 175).

Over time, cartographers moved Indigenous peoples off the page altogether, representing instead the European imperial imaginary of terra nullius, or empty lands; and of space as private property, and/or as sites of prospective exploitation of natural resources (DeRogatis, 2003). Blank spaces do not represent gaps in knowledge, but instead "actively erase (and legitimize the erasure of) existing social, and geo-cultural formations in preparation for the projection and subsequent emplacement of a new order" (DeRogatis, 2003, p. 33).

The dispossession of Indigenous peoples was then carried out under the European legal fiction of "terra nullius," and as Diane Smith points out, usually coupled with the 
enumeration of Indigenous peoples into "quantitative datasets and indicators that reflected colonial preoccupations and values" (2016, p. 120). In much of North America, maps were key instruments used in the rounding up and relocation of people into very small reserves in Canada, and reservations in the U.S., where their residual mode of production was almost impossible to continue, and they were subject to intense surveillance by police and other state institutions (Eades 2015).

\section{Maps, Extractivism and Treaties}

The history of the deep entanglements of Indigenous territories, the Canadian state, and oil and natural gas extraction stretches back to the late nineteenth century. The Dene of northern Alberta and the Northwest Territories had always known about the oil, had used it to waterproof their canoes, and may have traded it with other people (Nuttall, 2008). In 1899, the year of the Klondike gold rush in the Yukon and Alaska, the prospect of oil extraction prompted the national government to secure Treaty 8 with the Dene and other Indigenous nations, offering medical and educational assistance and treaty payments in return for extinguishing their title to the land and mineral rights. However, Dene Chief Drygeese and other leaders refused to sign away their rights, and instead declared they would continue carrying out their productive activities of hunting, fishing and trapping within their territories (Bryan and Wood, 2015).

Two decades later, when Imperial Oil set up a refinery in Norman Wells in what is still called the Northwest Territories, the federal government again sent a negotiating party north offering money, supplies and other guarantees in exchange for the land and extinguishment of rights. Treaty 11 was negotiated hastily, with vaguely stated terms, and considerable disagreement (Tesar, 2016); and the Dene again reiterated their rights to their territory (Piper, 2007, Bryan \& Wood, 2015). Nonetheless, the costs of extracting and 
transporting the oil remained prohibitive, and not much more activity occurred for fifty years.

Fast forward to the 1970s, when oil was discovered further north in Alaska's Prudhoe Bay. The economic, political and technological context had changed considerably. By then Canada had become one of the most energy-intensive industrialized nations in the world, with a complex system of pipelines reaching across the country. Yet, Canadian control over the oil and natural gas was far from secure. The concern of the Liberal Government of Prime Minister Pierre Trudeau, father of current Prime Minister Justin Trudeau, focused on three fronts: the U.S. oil barons' domination of operations in Alberta, competition from the oil producing states of OPEC, and the prospect of the U.S. and/or U.S.S.R. seizing sovereignty in the Canadian Arctic, which satellite and GIS-surveying technologies had made more possible.

However, the government had failed to seriously consider the fourth front: a resurgent Indigenous movement that had not ceded territorial sovereignty. In 1969, Trudeau's government proposed abolishing all existing laws relating to Indigenous peoples. They argued that the laws violated liberal principles of equality. Instead Indigenous peoples should be assimilated within Canadian society, and their lands privatized and turned into individual "fee simple" real estate that could be monetized (Manuel, 2015). Indigenous groups across the country soundly rejected the proposals as a thinly disguised attempt at “extermination by assimilation” (Cardinal, 1999). The ironically named White Paper helped to galvanize first nations, and led to the establishment of important regional, national and international political organizations, especially in the west, where many first nations reasserted Aboriginal title, demanded self-government, and Indigenous control over social, political and economic concerns. That same year, the Nisga'a nation, with Thomas Berger as 
legal counsel, initiated legal action against the British Columbia (B.C.) provincial government, declaring that their title to certain lands had never been extinguished.

Three years later, in 1973, the Trudeau government reversed course and proposed a land claims policy, priorizing areas of high (Read: extractivist) development potential. They proposed exchanging a package of rights and benefits in return for the extinguishment of Aboriginal title (Monet and Skanu'u, 1992). This reversal of fifty- two years of the government's denial of Indigenous land grievances was motivated by three events: the Liberal Party's political vulnerability as a minority government, the OPEC oil stand-off, and the decision in the Nisga'a case, in which the Supreme Court had determined that Aboriginal title had existed in British and Canadian law since the Royal Proclamation of 1763 (Bryan and Wood, 2015).

Concerned with the acute possibility of pipelines crossing their territories, the Dene and the Inuit decided to negotiate, even though they were well aware of the federal government's claim to control all decisions about non-renewable resources in the Northwest Territories (Coulthard, 2014). In what followed, both first nations used counter-mapping to challenge the state and oil company contentions, and as importantly, to reinvigorate their knowledge of their territory, and its significance for their ways of sustaining themselves, and reproducing their collective identities.

\section{Counter-mapping}

Maps afford a visual and nuanced perspective of place that can provide a graphic record of a people's historical, productive, social and spiritual relations within a territory. Nevertheless, like all data practices, mapping techniques and technologies are not neutral arbiters of truth, but rather, as Dalton and Stallman argue, "shape and facilitate the exercise of power." Mapping practices produce "geographic visions" that can either counter "predominant power 
effects" and "upset power relations," or be used for programs of state-building and capital accumulation $(2018,95-96)$.

Counter-mapping, as a participatory practice of a subaltern group, offered a visual medium to collectively assess and reassert control over conservation and natural resources (Willow, 2013), and challenge the hegemonic picture. As Peluso documented, countermapping allows a group to combine their own low-tech methods with the state's techniques and manners of representation in order to re-insert themselves and their lived experiences and perspectives, underscore their unique relationship to landscapes, challenge their disadvantaged circumstances, and get their territorial and customary claims to resources recognized by dominant settler societies (1995). During the 1970s, and the waning years of the Keynesian era, counter-mapping, like other forms of data activism, were powerful political instruments; they could help make issues visible and relevant, denounce hegemonic understandings, shed light on discrimination, and cement emerging social categories (Bruno, Didier and Vitale 2014). Nevertheless, much of the data activism of that historical cycle was circumscribed by the logics of the state (205).

\section{Pipelines, maps and sovereignty in Denendeh}

The Mackenzie River Delta Part stretches 1800 kilometers, with a watershed that drains $20 \%$ of Canada. It is home to the Dene (the Gwich'in, Sahtu, Tlicho, Deh Cho and the Yellowknives or T'atsaot'ines), who call the river Deh-Cho, the Inuit who call it Kuukpak, and the Métis peoples. During the 1950s, as Glen Coulthard, from the Yellowknives Dene has written, the economics and politics of Denendeh, or "land of the people," had dramatically changed. Until then, the Dene nations had contended with a fragile "articulation" between two ways of life - hunting, fishing and harvesting, and the emerging settler economy of waged labour, welfare and family allowance. Then, in the 1950s, when 
the federal government transferred regional administration to Yellowknife without consulting the majority Indigenous population, the non-native settler population rapidly increased, and with it, the pressure to adopt extractivism as the primary economic model. Fueled by their dispossession from the land, the Dene had developed a keen critique of colonial and capitalist development. In 1969, they established the Indian Brotherhood of the Northwest Territories which they renamed the Dene nation in 1978; and in 1975, they published a Declaration that re-asserted their status as a self-determining nation. Grounding their critique was an understanding of land that was distinct from the European capitalist concept; it combined three inter-related spatial dimensions: as a resource central to their material survival; as identity, constitutive of the Dene as a people; and as relationship (Coulthard, 62). "Place is a way of knowing, experiencing and relating to the world and with others; and sometimes these relational practices and forms of knowledge guide forms of resistance against other rationalizations of the world that threaten to erase or destroy our sense of place" (61).

Thus, when Arctic Gas (a consortium of Exxon, Gulf, Shell and others) and Foothills Pipelines proposed pipeline routes to the Canadian Government, without consulting with the Indigenous communities, the Dene and environmental groups launched protests and lawsuits. In response, the Liberal Government established the Mackenzie Valley Pipeline Inquiry, known as the Berger Inquiry after its Commissioner, Thomas Berger, who had earlier represented the Nisga'a in the landmark Supreme Court case establishing Aboriginal title in Canadian law. Under Justice Berger's leadership, the Inquiry set up public hearings in 35 communities, during which 1000 individuals and hundreds of expert witnesses testified (Bryan and Wood, 2013).

In preparation for the Berger Commission, the Dene conducted an extensive study. 
Phoebe Nahanni, an original signatory to the Dene Declaration of self-determination, led a team of twenty Dene researchers. Their first decision was to control the research process themselves, and not use outside white experts and/ academics. Recording on hardcopy maps and audiotape, they interviewed 546 people about their trapping, hunting, and other productive activities and practices on the land (Bryan and Wood, 2015). They then took the maps back to the communities to be re-checked, ensuring deeper accuracy and much wider collaboration in the larger project (McCall, 2011). Then, at each of the Hearings, a Dene field worker presented the maps that documented the historical and contemporaneous use of the land in that community.

The evidence they provided the Inquiry contradicted the colonial myth of terra nullius, that the land was empty of people, a productive economy and a system of land use protocols. As Nahanni said:

The maps clearly show what we have been saying all along before your legal institutions -that we have been here for hundreds and thousands of years; this is our land and our life. This is the most graphic demonstration of the truth that we Dene own 450,000 square miles of land...[T]he proposed oil and gas pipeline routes and construction sites conflict with our land-based activities... The implications of such intrusions not only affect the trails, travel routes, and trap lines; they also .... affect the animals, fish, lakes, and the environment and our way of life (Nahanni, 1977, p. 27).

After twenty-one months of testimony, Berger presented his findings. He was persuaded that the "income in kind from hunting, fishing, and trapping is a more important element in the northern economy than we had thought" (Bryan and Wood, 2015, p. 68); and concurred with the Dene about their right to establish control over the direction of their territory. He recommended that no pipeline be built along the north slope of the Yukon, and that a ten-year moratorium be placed on the Mackenzie Valley Project to allow time to settle Indigenous land claims and environmental issues (Coulthard, 2014). 
The Dene maps provided a graphic counter to the idea that extractivism was the only viable economic option, and the Canadian settler government the only political alternative. The mapping process also provided a performative and constitutive communications medium for the Dene; the community discussions about the maps and oral histories prompted inter-generational and intercommunity conversations. Like other counter-mapping projects, the maps provided an easily readable visual medium that helped in the collective re-imagination of territory and identity, one part of promoting discussion among the Dene communities about their past and future paths of development (McCall, 2011).

The Dene continued to use the maps; in 1980 they were transferred into one of Canada's first Geographic Information Systems (GIS) (Zoe- Chocolate, 2016); and in 2014, the Sahtú Renewable Resources Board (SRRB) used them in research about caribouharvester relationships, especially in relation to the impact of oil and gas exploration and development. Since the 1970s, the Dene and the Canadian state have engaged in many complex power negotiations, notable among which have been multiple government efforts to separate the recognition of cultural practices from socio-economic projects, and especially those that might potentially disrupt the extractivist model of development (Coulthard, 2014), the details of which are largely beyond the scope of this article. Nevertheless, it is important to underscore the Dene model of counter- mapping that linked economic uses of the land with collective projects of cultural and social revival.

\section{The Inuit maps and Nunavut}

The Inuit had also been re-organizing their political organizations during the 1970 s. The failure of the 1969 Liberal White paper, the Nisga'a Supreme Court case and the discovery of oil fields provided the impetus for the Inuvialuit in the Western Canadian Arctic to form the Committee on Original Peoples Entitlement (COPE) in 1970. The Inuit in the central and 
eastern Northwest Territories formed the Inuit Tapirisat of Canada (ITC) in 1971, which then proposed the establishment of a new territory that would give them control over wildlife and other resources, language, culture and political autonomy (Scobie \& Rodgers, 2013).

In 1973, the ITC initiated land claims negotiations, for which they were required to document their occupancy of their territory (Freeman, 2011). A team of 150 researchers, 120 of whom were Inuit, spoke to 1600 respondents in thirty-four (34) communities and produced an extensive three-volume report. The first volume drew entirely from Inuit sources about their contemporary and historical relations with their territory rather than European Canadian anthropologists and academics (Freeman, 2011). Importantly, the research team recognized the need to combine cartographic data with narratives, and introduced the technique of "map biographies," or extensive discussions with respondents about ancestral land use, names of places and their significance with contemporary Inuit land use, productive activities and collective identity. A second research project, the Nunavut Atlas Project conducted during 1985 and 1992, further interviewed hunters about archeological sites, subsistence and commercial fishing and hunting sites, campsites, outpost camps and major travel routes.

The evidence from the two projects provided the basis for the land claims agreement that established the new territory of Nunavut (our land in Inuktitut), on April 1, 1999. The Inuit Tapirisat surrendered Aboriginal title in return for financial compensation, exclusive ownership rights over much of the two million square kilometers and royalties from resource exploitation (Bryan and Wood, 2015). In addition, the value of the research project exceeded negotiations with the Canadian state; the two projects were important in deepening Inuit historical memory, inter-generational connections, and transfer of traditional knowledge, and 
of enrichment of collective identities. The mapping projects also provided the precedent for the Inuit communities of Quebec and Labrador to conduct similar research for land claims. In Labrador, the evidence from Our Footprints are Everywhere was used in the 2006 agreement that established Nunatsiaviut as an autonomous area in the province of Newfoundland.

\section{The legacy of the first cycle of counter-mapping}

The Inuit and Dene mapping projects led to a number of such studies around the world (Eades 2015, p.118); and set standards for all succeeding counter-mapping projects (Bryan and Wood, 2015, Usher, 2003). ${ }^{5}$ However, not all of these projects were designed or practiced in ways that would fit definitions of data justice, and/or were connected to larger projects of socio-economic and political justice. In some cases, map-making projects were entirely subsumed by state and corporate discourses, or worse, used to survey Indigenous peoples and their territories and justify extractivist projects (Bryan and Wood, 2014). In still other cases, as Simpson reflects, projects were taken up by white policy makers, academics and even Aboriginal organizations who naively operated with the idea that documentation of Indigenous knowledge of land use would lead to recognition by industry and the state who would then mitigate any negative effects of their development schemes $(2017,12)$.

Even when first nations designed the projects with goals of "land-based selfdetermination," as Willow found in her study of three cases in Canada and the U.S., "Indigenous people who choose to enact their sovereignty in this manner are indeed empowered, but only within an existing - and inequitable - socio-political system” (2013, p. 882). ${ }^{6}$ Nevertheless, Simpson argues that some Indigenous counter-mapping projects had long-lasting legacies: in her experience, even though the goals were constrained, the elders effectively used the process to "generate cohesion, pride and rebuilding" within their 
community. Critical messages about "dispossession, displacement, encroachment and industrial extractivism" were graphically communicated, as was the value of Indigenous intellectual thought and knowledge-making (2017, p. 12-13).

\section{The current cycle of extractivism, territorial and knowledge sovereignty}

The contest over maps and territories has only deepened in the current cycle of extractivism and extra-activism. Led by an Indigenous resurgence, a new assemblage of movements in Canada is targeting the oil and natural gas pipelines, whose impact engages a very long chain of people in rural and urban, Indigenous and non-Indigenous communities. Giving the motto of the Canadian state, "from sea to sea" a new meaning, anti-pipeline protests have emerged from coast to coast, expressing their opposition to the violation of Indigenous territorial sovereignty, and potential harmful environmental impact. ${ }^{7}$ In British Columbia, Indigenous nations, environmental, citizens' and other social justice organizations, and municipal councils, are mobilizing against the pipelines transporting tar sands oil from Alberta and fracked gas from northern B.C. Many first nations have banned the projects, articulating their unextinguished Indigenous laws through orders such as the Save the Fraser Declaration, the International Treaty to Protect the Salish Sea, and the Treaty Alliance Against Tar Sands Expansion (West Coast Environmental Law Association, 2017).

Key to this new extra-activist politics is a trans-media communications repertoire (Costanza-Chock, 2014), encompassing all manner of face-to- face, analog and digital media, including counter-mapping. The form and content of counter-mapping has also changed, "expanding into the variety of ways through which deep, spatial knowledge of a people, place and time is shared and communicated" (Bryan \& Wood, 2015, p. 179). Groups are combining analog and digital maps with much more extensive use of pictures, stories, songs and performances. Importantly, although the maps are still used as evidence in court 
and other proceedings with state institutions, much of the current Indigenous countermapping contests the pipeline companies directly. In addition, using all of the affordances of the digital ecology, maps are part of a repertoire of decolonizing knowledge for Indigenous and non-Indigenous alike, circulating across the country and around the world. They graphically represent the impact of extractivist capitalism and colonialism on Indigenous lands, bodies and ideas; and show the linkages between the eco-systems that they are protecting.

This latest cycle of contention dates back to the beginnings of the neo-liberal period of capitalism. During the 1980s, the International Monetary Fund and World Bank encouraged governments to invite foreign extractivist industries to develop their natural resources, arguing that the potential profits from exploiting oil, gas and minerals, including those now required for digital technologies (coltan, silicon, tantalum, palladium, etc.) could provide employment, tax revenue, trickle down wealth, and spill-on effects for local and national economies.

The Canadian government enthusiastically signed on. From 2006 to 2015, the Harper Conservative Government added even more measures to support Canadian extractive industries at home and abroad (Wilt, 208, North \& Young, 2013). Their flagship project, the Athabasca tar sands in northern Alberta, is the world's largest venture in size and capital investment, and stretches over 230 square miles. Like most extractivist projects, it required the building of extensive hydroelectric power grids, water and highway transportation corridors, pipelines and networks of digital and financial capital investment. The tar sands is not only one of the greatest contributors to global warming; it is toxic for living beings as huge volumes of water are extracted from the nearby waterways in order to separate the oil from the tarry substance called bitumen. 


\section{Trans-media assemblages}

Much like earlier Canadian governments, Prime Minister Harper's pro-extractivist policies included an attempt to remove First Nations' sovereign protection of their lands and waterways. In the fall of 2012, four women (three Indigenous women and one nonIndigenous ally) responded with a decentralized digital media and educational campaign (Duarte, 2017). Called themselves Idle No More, the movement quickly took off, with Indigenous activists, environmental justice supporters, and students forming flash mob rallies and teach-ins across North America, which were mapped on the Idle No More website and circulated through social movement networks around the world (Eades 2015. p.117). The "orchestrated assemblages of SNS, devices, various web platforms, and independent media channels" according to Pascua Yaqui member and scholar Marisa Duarte, allowed Idle No More and their allies, "to organise quickly and effectively, circulating messages, memes and actions that destabilised colonial efforts across First Nations lands" (Duarte, 2017, p. 6).

If the earlier focus of Indigenous activism in Canada had been a rights- based struggle with the state for recognition of their sovereign territories, knowledges, and forms of governance, Idle No More represented a significant political shift. Of course, the residual form continues in the courts and political forums. In addition, a number of Indigenous leaders have adopted the extractivist paradigm, attracted to the promise of jobs, investment and wealth as a remedy for the exceedingly high levels of Indigenous poverty and unemployment.

Nevertheless, a number of groups have rejected "the colonial politics of recognition" arguing that land claims and treaty processes have reinforced political and economic assimilation, reduced Indigenous territories to individually-owned property tracts, and 
instituted a flawed form of self- government in which local bands are required to manage their own oppression on very small reserve lands with minimal budgets (Warrior Publications, 2018). Instead, they are engaging in a de-colonial politics grounded on a critical refashioning of Indigenous customs and collective relations with the land, and sovereign legal and political traditions (Coulthard, 2014). They state that their long-standing traditional leadership has authority over their entire traditional territory and not just the tiny pockets of reserve land (Cochrane, 2019).

\section{First Nations Organizing, pipelines and maps}

The Wet'suwet'en, together with the neighbouring Gitksan, had employed extensive practices of mapping and oral history during the 1980s and ' 90 s in the long-running Delgamuukw versus The Queen (Eades, 2015). Although the eventual Supreme Court decision of 1997 did not resolve Indigenous land rights, it positively changed the law. Formally nullifying "terra nullius," the Court recognized the validity of the territorial claim of the hereditary chiefs, as well as their complex systems of governance and caring for their territories (Borrows 1999). The Court also recognized the legitimacy of Gitksan and Wet'suwet'en knowledge as evidence, which included oral histories, songs, and maps.

Currently, several different oil and natural gas pipelines are routed through Wet'suwet'en territory. Although several Indigenous band councils have signed agreements with some of the pipeline companies, the Wet'suwet'en hereditary chiefs have not signed and are actively oppose them. ${ }^{8}$ In 2010 , one of their clans, the Unist'ot'en, set up "an Indigenous reoccupation," building their first pit house right on the GPS center point of Chevron's Pacific Trail Pipeline, designed for tar sands oil. A precursor to Standing Rock, the goals of the Unist'ot'en camp include protecting their territory and salmon waterways 
against potential oil spills, nurturing their Wet'suwet'en knowledges and culture and practising territorial sovereignty.

They combine material and immaterial practices of mapping their territory. Drawing from the knowledge of their elders, they re-constitute their material bonds with the land, hunting, fishing, trapping, gathering, together with Indigenous and non-Indigenous allies. They have also created educational materials for the web, which map the inter-connections between waterways, fish and animal habitat, against the chain of pipelines and extractive projects in the larger region of northern B.C. Since 2011, they have practiced a variety of sousveillance techniques, using GPS and other means to intercept the surveyors from the pipeline companies and monitor the surveillance of the RCMP, the national police; encounters are documented and circulated via video.

\section{Mapping Pipelines, Putting up Tiny Houses}

The vast territory of the Secwepemc First Nation is south of the Unist'ot'en. They too have consistently asserted their sovereignty since first contact with the colonial state and extractive industries. During the 1970s, their visionary leader, George Manuel, was instrumental in founding the World Council of Indigenous Peoples, designed to build relations with indigenous nations of what he termed the "Fourth World," those peoples who

were trapped within First, Second and Third World states (Manuel, 2015, p. 169). ${ }^{9}$ Over the succeeding years, the network lobbied for the formal recognition of Indigenous human rights in international forums, and then, importantly, called out Canada and other national governments for their abuses of them. They were also instrumental in establishing the United Nations Declaration of the Rights of Indigenous Peoples, which is actively used by Indigenous peoples to challenge extractivism throughout the world (Kidd, 2015, 2016).

The current Secwepemc generation continues this legacy; together with 
environmental allies, they are using counter-mapping and a complex trans-media repertoire to contest the Trans Mountain pipeline, which would nearly triple the amount of oil transported through Indigenous territories. The Secwepemc campaign also targets the Canadian government, for while Justin Trudeau, the current Prime Minister, has received world headlines for speaking out about climate change, and reconciling with Indigenous peoples, his Liberal Government continues to support extractivism and argue that the pipelines are in the national interest. In late 2018, the Trans-Mountain pipeline was stalled at the Federal Court of Appeal due to inadequate consultation with first nations and failure to assess the impact on the marine environment. ${ }^{10}$

The Secwepemc also use a communications repertoire that links the material and immaterial. Their web-site combines maps with pictures and text to tell the history of their continuing resistance from first contact with Europeans to the incursions of the extractivist industry and the Canadian state. Using GPS, they have placed tiny houses in the path of the pipeline (Morin, 2017). When they wheeled the homes into a provincial park in July 2018 in an assertion of their title to their land, one of their leaders, Kanahus Manuel, was arrested; their live-stream of the event received more than 500,000 Facebook views (Brown \& Parrish, 2018).

The Secwepemc also collaborate with environmental organizations, and individual activists in creating other kinds of maps. The Western Wilderness Committee set up an interactive Kinder Morgan Pipeline watch map, showing the route of the pipeline, the impact on drinking water intakes, underground aquifers and salmon-bearing streams and the schools and parks the project. They encourage crowd-sourcing, inviting people to upload an app and report on any construction along the route and the sites of resistance. 8

\section{Data Justice: The Truth Won't Set You Free, but Organizing Will ${ }^{11}$}


Since the 1970s, Indigenous movements in Canada have used counter-mapping as one of the tools in their challenge to the hegemonic control of extractivist capitalism and the Canadian state, as part of their practice of "doing" territorial sovereignty (Willow 2013). During the 1970s cycle of Indigenous mobilization, counter-mapping was largely initiated and practiced in response to the Canadian state. They introduced their maps, together with other visual and oral media, in court proceedings and formal land claims negotiations as evidence of their territorial sovereignty since "time immemorial." The Dene, Inuit, and other first nations used effectively used counter-mapping in the partial recognition of their land claims. In the process they introduced very different forms of data, and procedures of knowledge and history making which challenged the hegemony of European-derived types of evidence, if still constrained by the grossly inequitable economic and socio-political systems, and ways of knowing. (Willow, 2013, Borrows, 1999).

However, the counter map-making practices of the Inuit, Dene, Wet'suwet'en and other first nations were not only about speaking to the power of the state. They also used mapping practices, together with narratives, songs, and prayers, to re-inscribe historical memories and revive their long-standing reciprocal relations with their territory and ways of life (Simpson, 2017, 14). The practices also generated a greater appreciation of the elders who participated in the research, local knowledge systems and land-use protocols; and provided graphic tools for a de-colonial critique of their history and a vision of a very different future.

A comparison of the two periods suggests two significant differences. Indigenous bands and nations that have rejected the treaty process use counter-mapping within a repertoire of struggle that deliberately exceeds the frame of "recognition." In addition, the affordances of digital technologies increased the scale and pace of data production and 
circulation beyond isolated Indigenous communities. Thus the tactics of sousveillance of pipeline companies and police, mobilization of local communities and allies, and decolonial education of Indigenous and non-Indigenous alike encompasses Indigenous and nonIndigenous allies across the country and in many other world regions.

These brief case studies of Indigenous counter-mapping in the Canadian extractive zone demonstrate how counter-mapping by itself, as with any genre of data justice, can never be substituted for long term political organizing (Concepción 2014). They demonstrate the importance of Indigenous control of data, a trans-media approach that builds on all the extant cultural and communications resources and ways of knowing of a particular group or movement. Echoing what MIT professor and data activist Sasha Costanza-Chock said at the Data Justice conference, they provide examples of data activism fused within larger projects of redistributive, transformative and restorative justice, which optimize their liberation and not the capitalist market (Costanza-Chock, 2018).

\section{References}

Awâsis, S. (2014). Pipelines and Resistance across Turtle Island. In T. Black, S. D’Arcy, T. Weis, \& J. Kahn (eds.) A Line in the Tar Sands: Struggles for Environmental Justice. Toronto: Between the Lines Press, 253-266. Borrows, Sovereignty's Alchemy: An Analysis of Delgamuukw v. British Columbia. (1999). Osgoode Hall Law Journal 39: 537-596.

Bruno, I., Didier, E., \& Vitale,T. (2014). Statactivism: Forms of action between disclosure and affirmation. Partecipazione e Conflitto:The Open Journal of Sociopolitical Studies. PACO, Issue 7(2), 198-220.

Bryan, J., \& Wood, D. (2015). Weaponizing Maps: Indigenous Peoples and Counterinsurgency in the Americas. New York: The Guildford Press.

Cardinal, H. (1969). The Unjust Society. Seattle: University of Washington Press. Chapin, M., Lamb, Z., \& Threlkeld. B. (2005) Mapping Indigenous Lands. Annual Review of Anthropology: 34, 621-622.

Cochrane, D.T. (2019) Corporations don't seem to understand Indigenous jurisdiction. The Conversation. January 16.

Collective, Counter Cartographies, Dalton, C., \& Mason-Deese, L. (2012) "Counter (Mapping) Actions: Mapping As Militant Research". ACME: An International Journal for Critical Geographies 11 (3), 439-66.

Concepción, C. (2014). The Use of Computerized GIS Mapping Systems in the Struggle for Environmental Justice. In R. Eglash, J. Croissant, G. Di Chiro \& R Fouché (Eds.) 
Appropriating Technology: Vernacular Science and Social Power, Minneapolis: University of Minnesota Press, 253-264.

Costanza-Chock, S. (2018). Data and Discrimination. Plenary Presentation, Data Justice Conference: Exploring Social Justice in an Age of Datafication. University of Cardiff.

Costanza-Chock, S. (2014). Out of the Shadows into the Streets: Transmedia Organizing and the Immigrant Rights Movement. Cambridge Mass: MIT Press.

Coulthard, G. (2014). Red Skin, White Masks: Rejecting the Colonial Politics of

Recognition. Minneapolis: University of Minnesota Press.Dalton, C., \& Stallman, T. (2018). Counter-mapping data science. The Canadian Geographer/Le Geographe canadien, 62(1), 95-96.

Dalton, C., Taylor, L., \& Thatcher, J. (2016) Critical Data Studies: A dialog on data and space. Big Data \& Society. January-June,1-9.

DeRogatis, A. (2003). Moral Geography: Maps, Missionaries and the American Frontier. New York: Columbia University Press.

di Chiro, G. (2004). Local Actions, Global Visions: Remaking Environmental Expertise. In R. Eglash, J. Croissant, G. di Chiro \& R. Fouche (Eds.), Appropriating Technology:

Vernacular Science and Social Power (pp. 225-252). Minneapolis: University of Minnesota Press.

Dyer-Witheford, N. (2008). For a Compositional Analysis of the Multitude. In W. Bonefeld, (Ed), Subverting the Present, Imagining the Future, Class Struggle, Commons, (pp. 247-

266). Brooklyn, N.Y.: Autonomedia.

Eades, G. (2015). Maps and Memes: Redrawing Culture, Place and Identity in Indigenous

Communities. Montreal \& Kingston: McGill-Queen's University Press. Epstein, A. (2015).

The Colonialism of the Present. An Interview with Glen Coulthard. Jacobin 2015: 1.

Retrieved https://www.jacobinmag.com/2015/01/indigenous-left-glen- coulthard-interview/.

Freeman, M. (2011). Looking back — and looking ahead - 35 years after the Inuit land use and occupancy project, The Canadian Geographer / Le Géographe canadien 55(1): 20-31.

Gardner, K., and Clancy, D. (2016) From Recognition to Decolonization: An Interview with Glen Coulthard. Up the Ante. Number 19. Retrieved

http://uppingtheanti.org/journal/article/19-from-recognition-to-decolonization/.

Harris, C. (2004) How Did Colonialism Dispossess? Comments from an Edge of Empire.

Annals of the Association of American Geographers, 94(1), 165-182.

Harris, L.M., \& Hazen, H.D. (2005). Power of Maps: (Counter) Mapping for Conservation. ACME 4(1): 99-130.

Hill. G. (2012) Stop the BC Treaty Process. Warrior Publications, March 29. Retrieved from WarriorPublications.wordpress.com.

Kane, L. (2018). Court ruling quashes approval of Trans Mountain. The Canadian Press, August 30. Retrieved https://www.ctvnews.ca/business/court-ruling-quashes-approval-oftrans-mountain-1.4073752.

Kidd, D. (2016). "Extra-Activism." Peace Review, 28:1, 1-9.

Kidd, D. (2015). "We Can Live Without Gold, But We Can't Live Without Water." In M.

Huff \& A. Roth (eds.) Project Censored 2015: Inspiring We the People. New York: Seven Stories Press, 223-243.

Klein, N. (2013). Dancing the World into Being: A Conversation with Idle No More's Leanne Simpson. Yes Magazine. March 5. Retrieved. http://www.yesmagazine.org/peacejustice/dancing-the-world-into-being-a-conversation-with-idle-no-more-leanne-simpson.

McCall, S. (2011). First Person Plural: Aboriginal Storytelling and the Ethics of Collaborative Authorship. Vancouver: UBC Press. 
Manuel, A. (2015). Unsettling Canada: A National Wake-Up Call. Toronto: Between the Lines Press.

Milan, S., \& van der Velden, L. (2016) The alternative epistemologies of data activism.

Forthcoming in Digital Culture \& Society,

special issue 'The Politics of Big Data' (2016). Available at SSRN:

https://ssrn.com/abstract=2850470.Morin, B. (2017). Activists in B.C. gear up for 'the next Standing Rock' with tiny house protest. CBC News. Sept. 7. Retrieved

https://www.cbc.ca/news/indigenous/kinder- morgan-pipeline-activists-tiny-houses-

1.4279740 .

Monet, D., \& Skanu'u. (1992). Colonialism on Trial: Indigenous Land Rights and the Gitksan and Wet'suwet'en Sovereignty Case. Gabriola Island: New Society Publishers. Nahanni, P. (1977). The Mapping Project. In M. Watkins (Ed.), Dene Nation: the colony within. Toronto: University of Toronto Press, 21-27.

North, L., \& Young, L. (2014) Generating rights for communities harmed by mining: legal and other action. Canadian Journal of Development Studies / Revue canadienne d'études du développement, 34:1, 96-110.

Nuttall, M. (2008). Aboriginal Participation, Consultation, and Canada's Mackenzie Gas

Project. Energy \& Environment. Vol. 19, No. 5, 617-634.

Peluso, N. (1995). Whose Woods Are These? Counter-Mapping Forest Territories in Kalimantan, Indonesia. Antipode 27(4): 383-406.

Piper, L. (2007). Subterranean Bodies: Mining the Large Lakes of North-west Canada, 1921-1960. Environment and History, Vol. 13, No. 2. May, 155-186.

Renzi, R., \& Langlois, G. (2015). Data Activism. In G. Elmer, G. Langlois \& J. Redden (eds.) Compromised Data: New paradigms in social media theory and methods. London: Bloomsbury, 202-225.

Scobie, W., \& Rodgers, K. (2013) Contestations of resource extraction projects via digital media in two Nunavut communities. Études/Inuit/Studies, Vol. 37, No. 2, 83-10.Simpson, L.B. (2017). As We Have Always Done: Indigenous Freedom through Radical Resistance. Minneapolis: University of Minnesota Press.

Sluyter. A. (2001). Colonialism and Landscape in the Americas: Material/Conceptual Transformations and Continuing Consequences. Annals of the Association of American Geographers. Vol. 91, No. 2, 410-428.

Smith. D. (2016). Governing data and data for governance: the everyday practice of Indigenous sovereignty. In T. Kukutai and J. Taylor (eds.) Indigenous Data Sovereignty. Canberra: Australian National University Press. Retrieved https://www.jstor.org/stable/j.ctt1q1crgf.14.

Svampa, M. (2015). The 'Commodities Consensus' and Valuation Languages in Latin America, Alternautas, 2(1), 49.

Tesar, A. (2016). Treaty 11. The Canadian Encyclopedia. Retrieved https:/www.thecanadianencyclopedia.ca/en/article/treaty-11/.

West Coast Environmental Law Association. (2017). Brief on Legal Risks for Trans Mountain.

Willow, A. (2013). Doing Sovereignty in Native North America: Anishinaabe Counter-Mapping and the Struggle for Land-Based Self-Determination. Human Ecology 41, 871-884.

Willow, A. (2016). Indigenous ExtrACTIVISM in Boreal Canada: Colonial Legacies, Contemporary Struggles and Sovereign Futures. Humanities 5, 55, 1-15.

Wilt, J. (2018). Canada's mining giants pay billions less in taxes in Canada than abroad. 
The Narwhal. July 16.

Zoe-Chocolate, C. (2016). Dene Mapping Project. A Paper presented to Borders in the North, Yukon College. Retrieved

http://biglobalization.org/sites/default/files/uploads/files/dene_mapping.pdf.

\section{Disclosure Statement}

No potential conflict of interest was reported by the author.

\section{Notes on Contributor}

Dorothy Kidd is Professor of Media Studies at the University of San Francisco, California. Her current research project examines contentious communications practices among frontline communities in the extractive zone. 
${ }^{1}$ Counter-mapping is one of several genres of critical mapping, including critical cartography, autonomous cartography, critical GIS, and public participatory GIS (Dalton \& Mason, 441442).

${ }^{2}$ Anna Willow used a similar term in her article Indigenous ExtrACTIVISM in Boreal Canada: Colonial Legacies, Contemporary Struggles and Sovereign Futures. Humanities 2016, 5, 55, 10.

${ }^{3}$ See Dyer-Witheford for the origins of the compositionist inquiry and an elaboration of his eight key questions (2008).

${ }^{4}$ See Dalton and Mason-Deese for a longer discussion of counter-mapping utilizing an autonomist framework.

${ }^{5}$ Many first nations in Canada have adopted critical mapping as core technologies, as have indigenous groups in Indonesia and Australia (Eades 2015), Colombia, Mexico and many other Latin American countries (Bryan \& Wood, 2015).

${ }^{6}$ Anna Willow (2016) compared three cases of Indigenous counter-mapping in Canada and the U.S. The Sokaogon in the northern U.S. framed their work within U.S. historic preservation legislation; the Grassy Narrows first nation in northwestern Ontario argued for recognition within their historical treaty relationship, and the Poplar River first nation within the framework provincial legislation in Manitoba and international support for indigenous rights (Anna Willow, 2016: 881).

${ }^{7}$ These mobilizations have included the Mi'kmaq Blockade on the Atlantic (Sub-Media, 2013), Elsipogtog in New Brunswick (Howe, 2015), and Line 9 in Ontario (Deutsch 2013). ${ }^{8}$ Their website includes text, videos and maps that outline their governance structure, and the principles on which they are operating. See http://unistoten.camp/about/governance-structure/

${ }^{9}$ For more discussion of their international organizing, see Arthur Manuel (2015), "A Fourth World: A Global Movement" pps. 167-178.

${ }^{10}$ On May 29, 2018, the Canadian government announced it would purchase the Trans Mountain pipeline from Texas-based energy giant Kinder Morgan for 4.5 billion Canadian dollars ( $\$ 3.5$ billion U.S.) in order to transport tar sands oil to Vancouver and onto China. In August, the Federal Court of Appeal struck down the federal government's approval of the project due to inadequate indigenous consultation and failure to assess the impact on the marine environment.

${ }^{11}$ This is the title of the Conclusion in G. di Chiro, G., 2004: 244. 